\title{
Early Presbyterian influences at the University of Pretoria
}

\author{
Graham Duncan \\ Department of Church History and Church Polity \\ University of Pretoria
}

\begin{abstract}
Presbyterianism, through two significant personalities, provided an important impetus to the formation and development of the early University of Pretoria. Their contribution has to be understood in terms of the contexts of their Scottish Presbyterian heritage, South Africa in the early years of the twentieth century and the state of higher education prevalent at that time. Together these contexts may be described as political, religious and educational. Prof AC Paterson made significant contributions both in teaching and administration at the institutional level. Prof E Macmillan made his contribution in the field of teaching, but never divorced from the very context where ministry has to be exercised.
\end{abstract}

\section{INTRODUCTION}

From the very beginning of its life and for a number of years, there is evidence of a Presbyterian influence at the University of Pretoria. Two significant characters in this regard are Prof Alfred C Paterson, first Rector of the University, and Rev Prof Dr Ebenezer Macmillan, lecturer in Theology. Prof Paterson made his contribution both in teaching and in the management of the University, while Prof Macmillan's main contribution was in the teaching of Theology.

\section{SOURCES}

With regard to primary sources, unfortunately, Paterson's writings are only accessible in the University of Auckland, New Zealand in a closed archive. This makes it difficult to assess Paterson's character apart from what others have written concerning him. There is a reasonable amount of Macmillan's writings available mainly in Lang (1945). Hence, it is possible to assess Macmillan both from his own writings and others' opinions of him. The University records and publications provide a small amount of information on 


\title{
Early Presbyterian influences at the University of Pretoria
}

both of these lecturers. The archives of the Presbyterian Church in South Africa (PCSA) do not have either of these men in their index, which indicates that they appear not to have played a significant role in church affairs. This is surprising in Macmillan's case because he was twice nominated and elected as Moderator of General Assembly and was Convener of the Assembly committee which produced an Ordinal and Service book for the PCSA.

Consequently, we are largely dependent on secondary sources for some of our information.

\section{CONTEXT}

Three contexts provide relevant background for this study; the general South African context of the early twentieth century, the situation in higher education and the particular Presbyterian ethos with which Paterson and Macmillan were infused.

\subsection{South Africa}

The broader context for this study is the post-South African War period. This was a war "fought to determine which white authority held real power in South Africa" (Davenport 1991:198). Alfred, Lord Milner (High Commissioner for South Africa and Governor of the Transvaal and the Orange River Colony) "hoped to place English-speakers on the land so as to break down the sharp occupational division between rural Afrikaners and urban British" (Davenport 1991:205). Further, there was an attempt to weld the four colonies into an:

\begin{abstract}
Anglicised and prosperous federated dominion within the British empire ... [which] depended in large part upon the mining industry, for it was expected to generate the "overspill" which would finance the resettlement of the Boers on their farms ... and the establishment of British and colonial families on the land.
\end{abstract}

(Cammack 1990:197)

"By this means, Milner intended to withhold political power from the whites of the new colonies until British ascendancy was assured" (Davenport 1991 :206). The language issue was employed as part of his "anglicizing [verengelsing] educational policy" (Spies 1984:362): "Dutch should only be used to teach English and English to teach everything else" (in Davenport 1991:206). This was an extremely contentious issue which posed a serious threat to the Afrikaner culture and became one source of rising Afrikaner nationalism during this period. Davenport (1991:212) has made a telling comment in this regard: "The Afrikaner people, saved from physical 
obliteration by Vereeniging, now needed to be saved from cultural obliteration at the hands of Milner's regiment of English-speaking teachers". The tense situation which existed between the Dutch and English speaking populations replicated the gap which separated the British imperial governments from its subjects north of the Orange River. This provided the opportunity for the rise of Afrikaner nationalism described by Lang (1945:13) in the post-union period as: "the storms that lay brooding so close ahead were mercifully hidden from sight, for otherwise there must have been grave doubt whether a craft so recently launched could survive so fierce an onset". These comments related not only to internal state matters but to the imminent war in Europe.

Milner aggravated the situation by importing a number of 'aloof and unpopular' (Cammack 1990) Oxford graduates (Milner's Kintergarten [Spies 1984:3263]) to staff top political posts. By 1925, South Africa was a dual medium nation though English was the language of recording.

\subsection{Higher education}

In the higher education context of the Transvaal, the clamant need towards the end of the nineteenth century was for higher education. In 1893, the Staatsmodelskool (Staatsgymnasium) was established in Pretoria. It was a normal college for the training of male teachers and had "the character of university teaching" (Theron 1984:62). Concurrently, the Volksraad was considering the legal obligations involved in the founding of a university. The outbreak of the South African War (1889-1902) put a hold on their plans and further developments would occur in a rather haphazard manner before the vision was realised.

In this regard the Kimberly Mining School was transferred to Johannesburg in 1904 and recognised as the Transvaal University College (TUC). At the same time, "Pretoria evening classes" and "Law classes" were introduced (Van der Watt 2003:12). 1907 was a significant year in the development of higher education. General J C Smuts became Colonial Secretary with responsibility for education, and with the assistance of $\mathrm{J} \mathrm{C}$ Adamson, Director of Education, he motivated a speedy resolution of the tertiary education matter. Smuts promoted the separation of Technology and Mining which would remain in Johannesburg and Literary Courses and Science Courses which would be established in Pretoria in spite of criticism of his approach. The college which was subsequently established in Pretoria was a branch of the Transvaal University College, Johannesburg. It would soon establish its own ethos with an emphasis on Humanities. 


\section{Early Presbyterian influences at the University of Pretoria}

Prof A C Paterson was one of the first four lecturers to be appointed made responsible for Classical Languages. At this stage very basic administration was formed.

\subsection{Presbyterian ethos}

Orr Macdonald (2000:12) offers a brief yet comprehensive summary of the essence of Presbyterianism which:

... evolved in Scotland as a religion of the Book, through a combination of reformed theology and ecclesiology, a vision of the "godly commonwealth", and a subsequent emphasis on strict federal Calvinist orthodoxy which formed the basis of the Catechism. This ethos was shaped and reshaped in the social and political context of post-Reformation Scotland: of Covenanters, union with England, the "golden age" of Scottish Enlightenment, dissent and evangelicalism. It was austere, not ornate; cerebral rather than emotional in expression. It was overwhelmingly a religion of proclamation and hearing, and hence it minimised the spiritual value of sight, smell, touch and taste. It emphasised striving and rectitude; good order; seemly obedience to authority; strict observance of the Sabbath. It included appreciation of the value of community and solidarity, and a periodically expressed desire for corporate reform in national life. But ultimately the stress was on heaven and hell; on individual effort and profession to prove worthy to a judgmental God.

Education was a key tool of the Reformation to promote such values, where a "lad o' pairts" could develop his God given gifts to the full extent of his potential. A key feature of the Presbyterian ethos was the powerful work ethic which drove Scots: "the right to work" was:

... a human right of self definition whereby it was possible to move $\ldots$ into active doing in the "real" public sphere. ... This is an exposition of the idea that work liberates, though personal dignity, creative production, freeing of aptitude and capacity, economic independence, the community of sharing a common task, and the engagement of body, mind and soul.

(Orr Macdonald 2000:352)

This was the tradition in which both Paterson and Macmillan were reared as children of the manse and they benefited from the opportunities which life in Scotland presented to them. 
The latter part of the nineteenth century marked a time when traditional beliefs and values were being assailed with the development of biblical criticism and liberal humanism. Both Paterson and Macmillan would have been aware of these developments if not directly affected by them. Traditional Calvinist orthodoxy was being challenged resulting in modifications to the Westminster Confession of Faith, the principle subordinate doctrinal standard of Scottish Presbyterianism. A further response was the Church's development of a social and economic critique. Further, German idealism resulted in, among other things, the rise of "Broad Church" and "High Church" tendencies within the Church of Scotland evidenced by the birth of the Church Service Society in 1865 (Burnet 1960:280). Macmillan was affected by this as can be seen from his leadership of the committee to prepare a more liturgically oriented service book for the Presbyterian Church of South Africa (PCSA).

\section{PROF A C PATERSON}

Alfred Croom Paterson was born on 12 February 1875 in the United Presbyterian Manse of Dalry (now Ardrossan) (Folliott to Registrar, 27 May 1959, File P/UP) in Ayrshire in the west of Scotland. He was the youngest of a family of thirteen. After being educated at Watson's College, Edinburgh (Folliott to Registrar, 22 July 1959, FileP/UP), he attended Edinburgh University and received the degree of Master of Arts (equivalent of a BA degree) in 1895, to be followed by a Master's degree in Modern Languages and Arts from Oxford University (Oberholzer 1992:60). Paterson became a teacher and emigrated to South Africa in 1903 following Lord Milner's visit to Oxford and Cambridge Universities to enlist support for his proposed restructuring of education in the Transvaal. He became part of Milner's Kindergarten with responsibility "to start country schools in the Transvaal after the war" (van der Watt 2003:17) with a view to the total Anglicisation of the education system (Oberholzer 1992:60). In 1905, he was appointed to the staff of the Pretoria College of Education.

On $11^{\text {th }}$ December 1907, Paterson was offered a post in the University College to be opened in Pretoria in 1909, from the beginning of 1908. His main responsibility was to teach Classics "and should be prepared to take Philosophy and Hebrew if the necessity should arise" (Adamson to Paterson, 11/12/07, File P/UP; n 11.12.1907, File P/UP, cf TUK Kalendar, 1919:19-20; cf Van der Watt 2002:12-13) though he also taught Latin and Ancient History (Ad Destinatum 1960:15) (he also had a capability in French and German). From February until July in 1908, he also taught Social Science subjects. He was described by Greyvenstein as "de knapste man voor Hebreeuwsch in 


\section{Early Presbyterian influences at the University of Pretoria}

geheel Zuid-Afrika" (Notule AKV 1919:28). Paterson, a man of exceptional intellect, had a great sense of duty and was a dedicated lecturer and academic. Being young his work was marked by great energy. He revealed a particularly open and convivial personality. He also became house father (Warden) at "The Residence", the hostel at the Education College. His command of "High Afrikaans" was good. He was described by an old acquaintance as "the most brilliant scholar and the most amusing personality" (Van der Watt 2003:18). Paterson's personality was that of a man "popular and appreciated" (Van der Watt 2003:19) with a great sense of duty, a self sacrificing, jovial Scot (a contradiction in terms considering the typical image of the Scots!) who was "fond of telling jokes - especially about Scotsmen!" (De Kock, biographical notes on Paterson, s a, File P/UP). In 1914, he married Uranie Perrin, widow of the entomologist C B Simpson.

It was only in 1916 that the first registrar was appointed to the University College in the person of Prof Paterson. From the beginning of his appointment, Paterson played a vital role in college affairs and demonstrated his skill in administration and finance (Ad Destinatum 1960:29). He carried this load with immense skill in addition to his teaching responsibilities. ${ }^{1}$ According to his contemporaries, he carried many of TUC's correspondence files in his head and could effortlessly recall their contents (a gift not necessarily shared by his successors!). His successor as registrar would subsequently remark "It is seldom indeed that one comes across a man with such a combination of qualities as he had: tremendous erudition, a brilliant intellect, a very keen sense of humour, coupled with business instinct, a flair for administration and immense energy" (Van der Watt 2003:17). As a result, susceptible to strain and stress, Paterson began to suffer from health problems. At this time, the Council and Senate decided to offer Paterson the position of first Rector. This had been under consideration for some time and there was a need felt for continuity and co-ordination (semi-illegible undated letter from the Judges' Chambers at the Supreme Court, File P/UP). He had already excelled both in the academic and administrative roles he had played. The issue of the appointment of a Rector was raised at this time, but it was decided to hold the matter over pending Paterson's return from overseas leave.

Subsequently, on 30 November 1917, Paterson was offered the post of Rector of the Transvaal University College and he accepted the position. The remit for the post of Rector was specific:

\footnotetext{
${ }^{1}$ By 1918, TUC had 325 students and 25 lecturers (Van der Watt 2003:19).
} 
To be responsible to the Council for the efficiency of the organisation and working of the College and, in connection therewith, to initiate with the Senate or with the Council, as the circumstances appear in his opinion to require, any action necessary for the promotion and maintenance of efficiency.

To be responsible for the general welfare of the students and to administer disciplinary regulations.

To further the interests of the College in every possible way, and to submit to the Senate or Council any proposal for new developments.

(Registrar to Under Secretary for Education 30 November 1917, File P/UP).

The overall aim of appointing a Rector was "that the establishment of the office of head of the College shall be a real step forward in its development as an instrument and centre of intellectual activity and general culture" (:ibid). The suggestion here is that the Rector should be the focus of academic activity and cultural development rather than simply an administrative position: "The Rector should be the exponent of the ideals and the activities of the College to the public" (:ibid). Public relations were a clear priority in the early days of the TUK's development. Interestingly, the title "Rector" was chosen due to the "similarity of nomenclature on both official languages" (:ibid).

In the meantime, Paterson had stated that he was no longer prepared: "... to continue to act as Registrar, Professor of Latin, and Lecturer in Hebrew, the work being quite beyond one man. He was however prepared to continue to act as Registrar and, with a view to holding his seat upon the College and University Senates, as Professor of biblical Hebrew." (Notule van die Senaat, 13 October 1917, 13 October 1917)

Health problems continued to affect him and in 1919, he resigned as Registrar. It was decided to appoint advocate A A Roberts as full-time registrar to assist Paterson. In 1920, Paterson tried to resign again and he became nominal professor of Latin; except for this he was relieved of all teaching responsibilities. A year later, the University at Johannesburg tried to lure Paterson away from TUK to accept a chair in Classics but the Council intervened and Paterson remained at TUK. The early growth and success of the college depended, to a large extent on the drive and energy of Paterson and his colleagues. Paterson was a leader of exceptional quality, the primus inter pares of a committed team. During this time, Paterson continued with some teaching responsibilities in Hebrew and while he was on leave during 1922-1923 (Notule van die Senaat, 8 November 1922, Min.11), his Presbyterian colleague, Prof E Macmillan gave his lectures. Though his 


\section{Early Presbyterian influences at the University of Pretoria}

Hebrew teaching was somewhat erratic due to his growing commitments, it is agreed that he did good work in this area (Oberholzer 1992:60).

Among his achievements, were the crafting of a university curriculum, the building of the campus with its ancillary services - "... for the first fourteen years of the life of TUK and until Professor Paterson's health broke down there was not a new development in which his guiding hand could not be seen" according to Dr Roberts (Van der Watt 2003:20). Management was his core activity and he took a keen interest in student affairs. He was involved in forming the structure for student affairs, amongst which were student societies. A Student Representative society was established in 1909. His open door policy endeared him to students. The first society to be established was the Literary and Debating Society. He, of course, was involved in the classical society "which flourished ... under the benign guidance of Prof A C Paterson" (Van der Watt 2003:20). He also took a supportive interest in sports activities as a result of his commitment to the mens sana in corpore sano principle.

This was a period of rapid expansion in TUC and Paterson was deeply involved in the acquisition of properties at Onderstepoort for veterinary science and locally for the experimental farm at the Faculty of Agriculture. This was in addition to the development of after hours facilities, the "University of Pretoria Campaign" and the Alumnus Association.

In light of this, it is surprising that Paterson's major focus was on financial administration (this may have had its source in his canny thrifty Scottish heritage!) to the detriment of community and relationship issues.

\subsection{Theology at TUC}

With Paterson's support, a Theology Department was established in 1917 at TUK with two professors. The motivation had come from the Nederduitsch Hervormde Kerk which had a desire to train its ministers in South Africa.

There was a need to seek the support of other churches in this regard and this raised the problem of the different approaches to dogmatic and non-dogmatic courses which would be taught by the church and university respectively (Engelburg Report, Notule van die Senaat, 10 July 1916:180). It was agreed that there was sufficient interest in the establishment of a faculty of theology and that the type of course preferred by the NHK would be acceptable to prospective partner churches, ie. all courses, except doctrine and the particular requirements of each potential participating denomination. 
The scheme submitted to the Minister of Education by the University Council "had explicitly specified the appointment of two professors, one Dutch speaking, the other English speaking" (Notule van die Senaat, 26 February 1917, min.4.i). Participating churches' professors appointed by the churches for their own dogmatic teaching purposes were to be recognised "on a footing of absolute equality as far as position and standing were concerned" (Notule van die Senaat, 26 February 1917, min.4.iii). The Faculty of Theology was formally constituted in November 1923 (Notule van die Senaat, 21 November 1923, Min.3).

By 1926, there were four professors, three from the Nederduitsch Hervormde Kerk and one from the PCSA. The Presbyterian post fell vacant in 1933 on the resignation of Prof E Macmillan. Just prior to this in 1932, the faculty had been divided into two separate sections, the Nederduitsch Hervormde Kerk and the Gereformeerde Kerk. Earlier discussion had taken place which included the Methodists and other unnamed churches (Engelenburg Report, Notule van die Senaat, 10 July 1916:180) but nothing seems to have come of this potential development (Ad Destinatum 1960:165).

\subsection{The "Medium Question"}

The language issue was a factor in Paterson's eventual departure from TUC. The matter has first been raised by students in the History Department, some of whom wished to have lectures in Dutch while others wanted to be taught in English (Notule van die Senaat, 13 April 1921, Min.29). However, duplication of classes was not possible due to financial constraints in a rapidly growing university (Notule van die Senaat, 21 February 1922, Min.3). Further, there were too few staff members to accommodate this demand. After considerable discussion, the Debating Society was formed using both English and Afrikaans. At that time, English was the official language for tuition and Afrikaans was not even an official language. Paterson became involved in the "conflict" and while he retired through ill health, his handling of the language issue was a contributing factor. Paterson himself favoured English because at that stage of the development of the Afrikaans language, the terminology was not sufficiently precise to meet the needs of academia, despite the fact that it was developing rapidly (Van der Watt 2003:26). He was serious in his attempt to use Afrikaans but in its purest form (Van der Watt 2003:26), in which he was himself proficient. The matter became controversial as the result of growing Afrikaner nationalistic sentiments among staff and students, who felt marginalised through the medium of English, and led to an almost obsessive need to promote Afrikaans. Paterson "had become disillusioned with the rising Afrikaner nationalism" (Sinclair 1983:134) but this was not surprising because 


\section{Early Presbyterian influences at the University of Pretoria}

it was, in part at least a response to Milner's "Anglicanisation" (verengelsing) policy.

The matter reached the University Senate (Notule van die Senaat, 4 September 1922) and a committee was established to consider the "Medium Question". It reported at the next meeting (Notule van die Senaat, 8 November 1922, Min.11) and it was decided that:

- $\quad . .$. in the matter of the medium of instruction in all departments that every appointment ... is to be made with reference solely to the ability and qualifications of the individual in his proper subject, with proviso only that he have adequate command of one at least of the official languages;

- That, however, the previous resolutions of senate viz. that the bilingual applicants should have preference where other things are equal, be affirmed.

In 1923, the TUC Council decided to adopt a parallel language policy insofar as finance would allow. Since all the Faculty of Theology students were Afrikaans speaking it was natural that the language of instruction would be Afrikaans though Paterson and Macmillan would still be free to teach in English (Ad Destinatum 1960:55.

This may have dealt with the situation on one official level, but there were clearly deep seated emotive issues related to the wider context of the Transvaal within the new Union at stake here. And it is quite possible that these were beyond Paterson's ability to resolve despite his apparently open personality. The developing nationalism was an issue that extended well beyond the university and could not be solely resolved within its confines. Paterson's natural inclination would be to favour English, and we must remember the basis on whish he was recruited for work in South Africa.

The Pretoria News (Van der Watt 2003:26) sensitively commented: "We believe that latterly he has felt that newer conditions at the college limited his scope, hence his decision' to resign". In a sense, it might be said that Paterson was a victim of contemporary political circumstances.

\subsection{Departure from the TUC}

In 1921, Paterson had given notice of his intention to give up the rector's position (Notule van die Senaat, 16 February 1921, min 2) at the end of the current financial year (i.e. 31 March 1921) as the result of ill-health. His decision led to the passing of a vote of no confidence by the Senate. 
However, Paterson agreed to remain in post until a successor was appointed. This took some time. What was needed was a person to mediate between the English and Afrikaans groups; this was an area in which Paterson had failed (Ad Destinatum 1960:31). On Paterson's resignation, the Senate passed the following resolution:

\begin{abstract}
Senate having learned with sincere regret of the departure of Professor Paterson, places on record its deep sense of the important and lasting service rendered by him to the TUC.

Attached to this institution from its foundation, Professor Paterson has helped to build it up from its small beginning; and by his sole and devoted [service] as Chairman of the Senate and Rector, has contributed materially to the extension of its activities.
\end{abstract}

(Registrar to Paterson, 27 February 1924, File P/UP)

He finally left the TUC in 1924 when he was appointed to a professorship in Classics at the University College of Auckland (University of Auckland, MSS \& Archives Collection, Inventory of 96/2), a constituent college of the University of New Zealand (Registrar to Folliott, 11 May 1959, File P/UP). There, he was described as "a very hard working Scot .... He was an impressive somewhat ponderous, very disciplined man, an excellent scholar, with a good knowledge of a wide range of languages; he could speak four fluently. Within a short time he transformed the teaching of Greek ..." (Sinclair 1983:134).

He became embroiled in the movement in New Zealand to establish separate universities, a cause which he took up "with great energy and enthusiasm" (Sinclair 1983:136). His South African experience had taught him that a federal university structure would lessen the financial support available to universities in a developing context such as New Zealand. His customary zeal led him to take up causes with great industry. He produced excellent results among his students; from 1924-1931 his students produced more first class honours degrees than any other department in the university, and more senior scholarships than in the years 1883-1923 (Sinclair 1983:174).

However, this took a considerable toll on his health and early in the 1930s he complained that he was near total breakdown as the result of exhaustion arising out of a very heavy teaching load.

He would return to South Africa twice in 1928 and 1931. During the 1928 visit, TUC was still trying to appoint a Rector. On this matter, Paterson commented: "South Africa generally is still a terrible country for politics" ( $\mathrm{Ad}$ Destinatum 1960:33). He died suddenly in 13 February 1932, after some minor surgery. 


\section{Early Presbyterian influences at the University of Pretoria}

Apart from being a Presbyterian by birth, there is no available evidence to indicate Paterson's role, if any, in the PCSA. There is no record in the minutes of the Session of St Andrew's Church (the only Presbyterian church in Pretoria) that he ever took up membership. Therefore, it is possible that, due to increasing commitments, he occupied the role of a nominal Presbyterian while in Pretoria. Otherwise, it is possible that he gave up formal association with his native Presbyterianism. Nonetheless, throughout his life he gave evidence of his Presbyterian background.

His total commitment to TUC is beyond criticism though he may have lacked sensitivity in the handling of the language issue. His strong sense of duty and dedication are well attested along with his enthusiasm, zeal, self discipline and passion. He sacrificed himself to promote his vision of a university college comparable to any in Europe. That this led to his ill health and departure from Pretoria is obvious.

\section{PROF E MACMILLAN}

Ebenezer Macmillan was also a son of the Manse in 1881, born to Robert and Sarah Macmillan in the Scottish highlands and reared in the manse of Ullapool. He attended school in Ullapool and at Hutcheson's Grammar School in Glasgow. He studied divinity at Glasgow University and spent some time also at Marburg where he would have been exposed to developments in biblical criticism. He was called to the ministry of Bearsden South in 1907. In 1911, he was called to the charge of St Andrew's, Pretoria. In 1917, Macmillan married Delscey Weir, daughter of a renowned judge.

The beginning of Macmillan's South African ministry occurred at both an interesting and exciting time for Pretoria had recently been chosen as the administrative capital of the newly created Union of South Africa.

In addition to the demands of a constantly enlarging parish and his denomination (in which he was responsible for the onerous task of preparing a new service book, 1921), in 1918 Rev Ebenezer Macmillan began to teach the History and Philosophy of Religion at the Transvaal University College to theological students as a part-time lecturer, having been nominated by the PCSA. He was already involved in the Theological Training Committee of the PCSA and anticipated that his denomination could enter nine candidates (Van Nieuwenhuizen 1974:34). The PCSA had decided to replace its ad hoc training policy as a result of "the great development of University education in South Africa" and instructed its Theological Education Committee to: Consider the possibilities of the new situation with the object of obtaining either separately, or in conjunction with other denominations, and in close association with the University authorities, a more satisfactory training than is 
possible at present, with hostels to secure denominational atmosphere (PCSA General Assembly 1918, Theological Training Report, Resolution 5, AC 1971, Ah1.3-1.4, William Cullen Library [WCL], University of the Witwatersrand).

Three years later, no progress having been made, the General Assembly specifically recommended that potential candidates for the ministry be advised to use the endowed facilities which have been provided for theological study at the Transvaal University College (PCSA GA, 1921, Theological Training report, Resolution 3. WCL). This was followed be a decision to adopt a full university course for ministry requirements (PCSA GA, 1924, Theological Training Report, Resolution 3. WCL) "for European candidates" (PCSA GA, 1925, Theological Training Report. Resolution 2, WCL). In the event no Presbyterians ever registered at Pretoria during Macmillan's time, despite there being a query from one Presbyterian; this situation would only be remedied in 2002. At the time of the formation of the faculty, the prospective participating denominations had not been able to give guarantees concerning the take up of student places (Van Niewenhuizen 1974:33)

Macmillan also taught Hebrew and his theology was assessed as "geheel modern" (Notule Kuratorium, 22 July 1919) by some. Macmillan refused to take a confessional approach in his teaching; this could have been done in a denominational school which his own denomination has constantly eschewed as a means of preparing its candidates for the ministry; he rather preferred the descriptive method. His approach was governed by a strict integrity:

And what of the Bible in the light of modern criticism - do our young people know anything of the work that is being done to recover the true inwardness of the beginnings of Christianity? - a work only comparable with that of Luther and the Reformation, who were themselves a return to the religious experience of the early church.

(Moderatorial Address, 1923 in Lang 1945:58)

Here Macmillan drew the spiritual and the academic into a close relationship particularly in ministerial formation: "... the supreme need of the Christian ministry is spiritualisation”. (Moderatorial Address, 1923 in Lang 1945:61.) It was related to spiritual leadership. A regular devotional life was of its essence: "It meant taking time with God so that He might tell not only their own needs but other peoples' needs. Christ took time alone with God for His disciples. So He was able to correct this tendency to weakness or to encourage that 


\section{Early Presbyterian influences at the University of Pretoria}

possibility of strength; and so build them up for leadership". (Sermon on John 21:16, on Lang 1945:115.)

Macmillan abhorred a narrow denominationalism, as a lecturer and as a churchman:

We must overstep the bounds of our denominationalism, and transcend the limitations of our Protestantism, by seeking to recover the inheritance of the saints. As the nineteenth century felt its was safe to be religious, so the twentieth is going to feel it must be religious, no matter the risk".

(Moderatorial Address, 1923, in Lang 1945:21)

He represented the best in both the Reforming and Presbyterian traditions which have always been ecumenical in their essence as part of the one, holy, catholic and apostolic Church.

As a Reforming theologian, Macmillan challenged the notion of infallibility derived from sacerdotal authority, with the exception of the testimonium internum Spiriti Sancti as a foundation for a universalising discipline and vision. He eschewed "the sterilising influence of a cold intellectualism" as well as a sentimental approach to matter of faith (Lang 1945:23). He asked "how many of us can say that we are fulfilling the apostolic injunction to 'maintain the spiritual glow?' How far has the primacy of things spiritual over things material kept its place in our lives, in our conversations?" (1935:5). And he did not consider Ethics to be an adequate substitute? His solution was the preaching of a Gospel infused with an "evangelical passion" (Macmillan, Moderatorial Address, 1935:4). This is the source of Macmillan's notion of authority derived from the Word preached and celebrated in the sacraments (ibid:5), and manifested in the principle that: "The Christian life is still the best argument for the truth of the Christian faith, the only argument that will convert this unbelieving generation. To live the Gospel is the best way to preach it" (ibid:5).

Quoting von Hugel, Macmillan claimed that "in every Word of God there is ... 'a givenness', which seals its authority and will be proved by its results" (ibid:5). Macmillan had captured the essential elements of a holistic approach to theological education and ministerial formation.

The course at TUK as originally planned, was to be, it was hoped, interdenominational but in the event students of the Hervormde Kerk alone attended the lectures. It was work which first brought him into intimate touch with Afrikaans-speaking youth, and it was soon evident how much their quality impressed him. "His own radiant vigour of mind made an irresistible appeal to 
students and he in his turn responded readily to the attraction of their spirit and outlook" (Lang1945:19). In October 1924, he was appointed part-time professor (Registrar to Macmillan, 27 October 1924, File M/UP) in Science of Religion and Missiology with the aim of focussing on the science and history of religion.

In 1925 he joined Dr Donald Fraser of Gooldville Mission, Venda, in a national mission and sought permission to involve students (Macmillan to Roberts, 29 June 1925, File M/UP) as part of their practical exposure and training. This campaign sought to bring together all the Christian and moral forces which would unite and advance both the Christian and humanitarian causes in the face of the urgency of his day: "If we are not missionary, there are pagan forces which are. There is vision and direction behind them. While we are only visionary, they are missionary" (Macmillan 1935:5). In addition to this, Macmillan also exercised a faithful prison ministry as well as that of Liaison Officer between the Royal Air Force and the South African Air Force.

\subsection{Moral Re-Armament}

He carried on this work till 1933 when "he found it necessary to find some respite from a variety of strain which even his vitality could no longer carry, and regretfully he severed his connection with the College" (Lang 1945:19). He had been asked to accept a full time position but he declined because he had been becoming more deeply involved with the Oxford Group ${ }^{2}$ since 1929. In that year, he requested that he be permitted to take two months leave in order to participate in a "mission" to Scotland by the South Africa Group of the Oxford Group (Macmillan to Rector, 26 November 1929, File M/UP). The Council awarded him up to three months leave (Macmillan to Secretary of Council, 19 December 1929, File M/UP). This happened again in 1931 and in 1932, and on each occasion Macmillan made appropriate arrangements for his lectures to be covered.

The Oxford Group was probably one of the sources of his being "always quick to champion the cause of the underprivileged [as] he ... sought to secure justice and opportunities for ... black fellow countrymen" (Burns 1990:26). Macmillan was not hesitant when it came to entering the arena of "political" concerns. The 1920s marked a time of industrial strife. He entered the fray and challenged assumptions which were dearly held: "... were there a

\footnotetext{
${ }^{2}$ The Oxford Group, begun by rev Frank Buchman, grew into the Moral Re-Armament Movement formed in 1938. The Movement had Christian roots and its philosophy was based on the "Four Absolutes": absolute honesty, absolute purity, absolute unselfishness and absolute love. Its method is to wait for God to give guidance on every aspect of life and submit to that advice. MRA encouraged its members to be involved in social and political issues. Its theory begins with self transformation leading to societal transformation. Its name was to Initiatives for Change in 2001.
} 


\section{Early Presbyterian influences at the University of Pretoria}

true Christian commonwealth in this country ... there would be, there could be, neither strikes nor revolutions of any kind". His views were based in his belief in co-responsibility:

We would have you bear in mind that there are no such things as rights which have not also their correlative duties. So if you insist on your rights, you must have a sense of your duties as well, not only to yourselves or your unions, but also to your employers and to the social state as a whole (in Lang 1945:16).

Here Macmillan was addressing the workers whose cause he had supported prior to the outbreak of violence. However, we can only wonder what message he had for their employers many of whom occupied pews in St Andrews regularly?

In his 1923 closing Moderatorial Address, he challenged the denomination: "The time is overdue for the Church to declare its attitude and policy towards the native people of this land; and in the present grave condition of affairs, we must act with united and consecrated force" (Lang 1945:22). Macmillan saw the faith as a dynamic force in society: 'It will never do for the Church to stand merely on the defensive' (1935:5). He had never been of the view that reconciliation was a matter between to two European races but must include all South Africans, and here he was convinced that it was primarily a matter of justice and opportunity for all. His commitment to MRA was linked to his passion for building one nation. In this regard, he implored "THE TREK MUST GO ON"! (St Andrews Day, 1938 in Lang 1945:122).

\subsection{Race and reconciliation}

This was a cause adopted by Macmillan for regular attention during his Pretoria ministry. This had two aspects; the first was the relationship between the Afrikaans and English speaking populations; the second was the reconciliation of races in South Africa. For him this was a matter of justice that required reconciliation through restitution. This was his passion.

The aim of reconciliation between Boer and Brit was not an end in itself, but part of the greater hope that together they might work for the upliftment of black people. He suffered from a sense of superiority, common for his time regarding the place and involvement of blacks in their own empowerment. He took up this theme "Nation building and the call to Moral Rearmament" in a sermon delivered on St Andrew's Day, 1938 (Lang 1945:122-128), the year of the anniversary of the Great Trek. His lofty vision was "our common South African nationhood, and how it may be built up into something great and strong, for service, not only to South Africa, but to the 
whole of Africa, to the British commonwealth and to the nations of the world" (ibid:122). He foresaw in a prophetic way, that in the future South Africa would not remain: "in a backwater, isolated, out of the mainstream of the world's life. I see it united and free, playing a determinative part in the reconciling and uplifting of the world" (Sermon on Hebrews 11:14-15, St Andrews Day, 1939 in Lang 1945:147-148).

Macmillan certainly saw South Africa as a potential exemplar to the world in the field of race relations. From his experience of historic oppression as a Scot, Macmillan attempted to forge an identity with the Afrikaner "in realising a national consciousness" (ibid:123). This Scottish experience had taught him that "Scotland became a nation, not living for itself alone or in the first place, but for the other nations that shared the same ideals of government, and for the world at large" (ibid:124). He offered up his Scottish experience as an authentic offer, "but our identification must be complete" (ibid:124). He acknowledged that the English-speaking population had been complicit in segregation through failing in its task of identification through expressions of superiority leading to a sense of self sufficiency and individualism. The resolution of this problem could be sourced in a "new moral discipline" (ibid:125), i.e. MRA. But it could only take place in the South African context, nowhere else. Therefore it required commitment to reconciliation as "real relationships" (ibid:125). In his own case, Macmillan demonstrated his personal commitment: "I could not see South Africa or take real responsibility for it or be identified with it, until I had cancelled the option on that plot" (ibid:125), a piece of land he wanted to acquire for his retirement in Scotland. "It is something I can so easily reconcile, if my identification is to be complete" (Lang 1945:147).

In the main Macmillan addressed the sphere of race relations between the white groups. He acknowledged something which English-speaking South Africans have been loath to admit:

We ...must take responsibility for our share in keeping the races apart, by our failure to be utterly identified with South Africa, its soil, its language and its people. ... There has been a race superiority or pride that has made us seem self-sufficient. There has been patronage instead of that real humility, which is willing to be identified with the other race on a basis of equality.

(St Andrew's Day, 1938 in Lang 1945:124)

He referred to the erosion of vital values. To those of Scottish descent, he issued a challenge to establish an indigenous patriotism (Lang 1945:144). He 


\section{Early Presbyterian influences at the University of Pretoria}

linked repentance to restitution as components of reconciliation but these were vital to relationships between all white people in South African society, "putting back into the earth and giving back to the people more than we have taken out" (in Lang 1945:143). Here he was referring particularly to "poor whiteism" (ibid:143). This could also have been a helpful analogy in integrating the black population too with their spiritual, as well as economic, adherence to the land. Macmillan's stimulus towards integration was a direct result of his Christian commitment galvanised by his attachment to Moral ReArmament. His links with the TUC were probably largely responsible for his attitude and concern in the matter of race relations, working largely as he did with Afrikaner staff colleagues and students.

The integration of Afrikaner and British would provide a firm foundation for "the hope that it afforded, that they might set themselves at last to the task of developing the child races entrusted to their care" (Lang 1945:31). The paternalistic language of trusteeship apart, there was a clear priority in Macmillan's approach to total racial reconciliation. It was something that was done to and for others with little regard to what the so-called "child races" could do for themselves. Spiritual change was an integral part of this process (Address to the Church of Scotland General Assembly, 1936 in Lang 1945:31).

With regard to the position of blacks, Macmillan was practically concerned with poverty: "There ought to be no poverty in this land, for black or white. It ought to be possible to remove from all our people those fears of having to do without food, shelter, employment and of destitution in ill-health or old age" (Lang 1945:143).

He acknowledged that the prevailing situation was the result of racial difference which had an economic base: "The reason for our division is largely economic. ... We are divided ... race from race" (ibid:143). He had challenged the General Assembly of his church in 1923: "The time is overdue for the Church to declare its attitude and policy towards the native people of this land". To some extent he was aware of the church's role as a servant of power (Cochrane 1987).

Macmillan passed away suddenly in 1944 after having suffered a stroke. Like Paterson, his many and firm commitments had weakened the body though not the spirit. He had constantly put his family life on hold. His daughter Barbara recorded that her father's death "brought home to us how deep had been the deprivation of family life during those years" (Burns 1990:31). He frequently "took little holiday during the year but tried to save in order to visit Scotland every five years" (Burns 1990:31). In time all his many areas of service had "exacted their full toll of Mr Macmillan's energies" 
(Lang1945:20). Twice, as Moderator of the General Assembly of the Presbyterian Church of South Africa (PCSA, in 1924 and 1936), he "gave himself without stint to the service of his folk and the duties of his office" (Lang 1945:21). On the morning of his death, Macmillan recorded the following:

\begin{abstract}
Reading Corinthians II v17-18 ${ }^{3}$ - the summing up of pride. ... When I preach in His name do I believe that he is with me and will use me? If not, He can't ... "Attempt great things for God. Expect great things from God". Lord help me this day in all humility and simplicity to speak for Thee. Let me have no thought of myself at all or of the people who may be there in Church. Even if there is no one. May I only look forward to my meeting with Thee. May that meeting be determining of my life this day, giving me the words to speak and the power to speak them.
\end{abstract}

(Burns 1990:32)

Little did he realise how soon that meeting would take place.

With the support of his Session and the University College, Macmillan constantly overburdened himself as he felt called to expand the range and scope of his ministry. He had constantly sought the grace to bear the load he imposed upon himself through self discipline believing that "He never said it would be easy, but He did promise it would be without strain" (20.XI.43 in Burns 1945:43). Among his other distinctive contributions, Macmillan has provided us with the essential elements of a model for theological education we would do well to emulate. He was a model of the Scottish academic theologian who was grounded in the work of a parish, and Macmillan was never able to break this link. His ministry was a true reflection of the praxis approach where ministry is a constant reflection on ministerial practice with a view to further improved dedicated service. It is:

"reflective action", that is, a practice that is informed by theoretical reflection, or, conversely, a theoretical reflection that is informed by practice. ... The term praxis attempts to keep theory and practice together as dual and mutually enriching moments of the same intentional human activity.

(Groome 19980:xvii, n 1)

\footnotetext{
3 "If anyone would boast, let him boast of the Lord. For it is not the one who recommends himself, but the one whom the Lord recommends, who is to be accepted" (REB)
} 


\section{Early Presbyterian influences at the University of Pretoria}

In all his work he was essentially a reconciler. This was a combination of his deep Christian responsibility and his commitment to the MRA movement. Compared with Paterson, we may note here a somewhat more irenic spirit.

\section{CONCLUSION}

Both of these distinguished academics made significant contributions to the growth and development of the University of Pretoria. Their work was marked by great drive, enthusiasm and commitment which were total. They were passionate about their work and gave it their all while attached to the university. With regard to Paterson's contribution as a Presbyterian, as with Macmillan, it might be best to reiterate the truism that you can take the man out of Presbyterianism (Paterson to the TUK and Macmillan to MRA), but you cannot take Presbyterianism out of the man. Nor was it possible to neutralise the deeply seated Protestant work ethic. They are good examples of diligent Scots, an authentic product of his Scottish background, a product which has been found to be eminently exportable and of which I am proud to be a successor.

\section{Works consulted}

Ad Destinatum 1960. Gedenkboek van die Universieit van Pretoria. Johannesburg: Voortrekkerpers.

Burnet, G B 1960. The Holy Comunion in the Reformed Church of Scotland, 15601960. Edinburgh: Oliver \& Boyd.

Burns, B 1990. Ebenezer Macmillan 1881-1944 in Cuthbertson, G (ed), Presbyterians in Pretoria: St Andrew's Church, 1889-1999, 17-32. Pretoria: St Andrew's Presbyterian Church.

Cammack D 1990. The Rand at war: 1899-1902. The Witwatersrand and the AngloBoer War. Pietermaritzburg: University of Natal Press.

Cochrane J R 1987. Servants of power: The role of the English-speaking churches in South Africa, 1903-1930. Johannesburg: Ravan.

Cuthbertson, G (ed) 1990. Presbyterians in Pretoria: St Andrew's Church, 18891999. Pretoria: St Andrew's Presbyterian Church.

Davenport, T R H 1991. South Africa: A modern history. London: Macmillan.

Groome TH 1980. Christian religious Education: Sharing our story and vision. San Francisco, CA: Harper \& Row.

Lang, J (ed) 1945. Happy seeker, happy finder: A memoir of Dr Ebenezer Macmillan of St Andrews Church, Pretoria with some sermons an addresses. Pretoria: Van Schaik.

Macmillan E 1935 (1978). The conversion of the church. Christian Leader February 1978:4-5.

Muller, C F J (ed) 1984. 500 Years: A history of South Africa. Pretoria: Academica. Nederduitsch Hervormde Kerk 1919. Notules van die Kommissie van die Algemene Kerkvadering van die Nederduitsch Hervormde Kerk. Pretoria: NHKA. 
Nederduitsch Hervormde Kerk 1919. Notules van die Kuratorium vir die Teologiese Opleiding van die Nederduitsch Hervormde Kerk. Pretoria: NHKA.

Notule van die Senaat, 1916-1922. University of Pretoria.

Notule van die Universiteitsraad, 1910-1925. University of Pretoria.

Oberholzer, J P 1992. Die Ou-Testamentiese Wetenskap in die Fakulteit Theologie (Afd A), Universiteit van Pretoria, 1917-1982. HTS 48(2), 59-65.

Orr, Macdonald L A 2000. A unique and glorious mission: Women and

Presbyterianism in Scotland, 1830-1930. Edinburgh: John Donald.

Presbyterian Church of South Africa (PCSA). Minutes of General Assembly Minutes of Theological Training Committee. William Cullen library, University of Witwatersrand.

Personnel Files: Prof C Paterson (File P/UP), Dr E Macmillan (File M/UP), Human Resources Department, University of Pretoria.

St Andrew's Presbyterian Church 1905-1930. Session Minutes. Pretoria: PCSA.

Sinclair, K 1983. A history of the University of Auckland, 1883-1983. Auckland: Auckland University Press.

Spies, S B 1984. Reconstruction and Unification, 1902-1910, in Muller (ed), 362-384. Theron B M 1984. Social history of Pretoria during the first phase of the Anglo-Boer War: October 1899-1900. MA dissertation. Pretoria: UNISA.

University of Auckland, MSS \& Archives Collection, Inventory of 96/2.

Universiteit van Pretoria 1916-1930. TUK Kalender, Pretoria: Universiteit van Pretoria.

Van der Watt, F 2003. Rectores Magnifici. Pretoria: Protea.

Van der Merwe, P J \& Crafford, D 1992. Die Departement Godsdiens en SendingWetenskap (Afd A), Universiteit van Pretoria, 1917-1978. HTS 48 (1\&2), 331361.

Van Nieuwenhuizen T H J 1974. Ontstaan en Geskiedenis van die Teologiese Fakulteit (Afd A) aan die Universitieit van Pretoria: 'n Oorsig. BD proefskrif, Fakulteit Teologie, Universiteit van Pretoria. 